ks. Artur Hałucha ${ }^{1}$

Uniwersytet Papieski Jana Pawła II w Krakowie

\title{
Duszpasterstwo specjalne na przykładzie duszpasterstwa niesłyszących a II Sobór Watykański
}

19 sierpnia 2011 roku prezydent Rzeczypospolitej Polskiej podpisał w Sejmie Polskim ustawę o języku migowym i innych środkach komunikowania się². Zwrócił w ten sposób uwagę na grupę ludzi, która stanowi ważną część naszego społeczeństwa, a jej głos i potrzeby są niekiedy marginalizowane. Warto w takiej sytuacji podjąć refleksję nad tym, co czyni Kościół wobec osób niesłyszących.

Założyciel Kościoła Jezus Chrystus podczas spotkań z ludźmi szczególną uwagę poświęcał osobom chorym, niepełnosprawnym, żyjącym na marginesie życia społecznego (zob. Mt 8, 1-4; 14-17; 9, 1-8; 18-38; 12, 9-14; 14, 34$36 ; 15,29-31 ; 17,14-21 ; 20,29-34 ; € k 23,33-34)$. Apostołowie byli kontynuatorami tej troski. Św. Paweł napisał: „,bylebyśmy pamiętali o ubogich, co też gorliwie starałem się czynić" (Ga 2,10). Do ubogich tego świata ze względu

1 Artur Hałucha - magister licencjat teologii, kapłan diecezji Ełckiej, od 2011 roku doktorant homiletyki na Uniwersytecie Papieskim Jana Pawła II w Krakowie, od 2002 Diecezjalny Duszpasterz Niesłyszących Diecezji Ełckiej, posiadający certyfikat zaawansowanej znajomości języka migowego. Wykładowca języka migowego i spowiednik w WSD w Ełku; absolwent Studium Retoryki na wydziale Polonistyki Uniwersytetu Jagiellońskiego w Krakowie.

2 Zob. Dz. U. z 2011 nr 209 poz. 1243, www.isap.sejm.gov.pl/DetailsServlet?id=W DU20112091243. 
na brak słuchu zaliczyć można także niesłyszących, czyli takich, którzy nie słyszą od urodzenia lub wczesnego dzieciństwa i nie rozwinęli umiejętności mówienia ${ }^{3}$. Zwani są także głuchymi, głuchoniemymi lub niesłyszącymi kulturowo ${ }^{4}$.Jest to niemała populacja. Według danych Światowej Organizacji Zdrowia z 2013 roku na świecie żyje ich ponad dwieście siedemdziesiąt pięć milionów, z czego w Polsce blisko pięćdziesiąt tysięcy5. Ze względu na brak słuchu niesłyszący posługują się w komunikacji językiem migowym, ze specyficzną jego gramatyką, uwzględniającą mimikę twarzy i przestrzeń. Jest to gramatyka odmienna od gramatyki języków narodowych. Niesłyszący mają utrudnioną komunikację ze światem ludzi słyszących, stąd niestety przez szereg lat byli postrzegani jako osoby z niższym stopniem rozwoju intelektualnego.

W 1927 roku Aleksander Brücnker w Słowniku etymologicznym języka polskiego ${ }^{6}$ postulował, aby uznać, że wyraz „głuchy” i „głupi” pochodzą z tego samego rdzenia. Ta krzywdząca etymologia oraz brak odpowiedniej znajomości języka migowego przez większość słyszących zbudowały barierę komunikacyjną, w której populacja słyszących zaczęła traktować osoby niesłyszące jako upośledzone. Choć do czasów współczesnych wiele zmieniło się na plus w podejściu do niesłyszących, to jednak słowa cenionego surdopedagoga Kazimierza Kirejczyka (1910-1986), napisane już prawie 60 lat temu, nie tracą na aktualności: „Głusi jeszcze dzisiaj napotykają często w swym życiu mur uprzedzeń, niechęci, niedowierzania, a nawet niekiedy nieuzasadniony lęk

3 K. Półtorak, Duszpasterstwo niesłyszacych, [w:] Duszpasterstwo specjalne, red. R. Kamiński i D. Drożdż, Lublin 1998, s. 157.

4 Por. B. Szczepankowski, Słownik liturgiczny języka migowego, Katowice 2000, s. 10.

5 Liczba osób z uszkodzonym słuchem w Polsce jest trudna do ustalenia, a precyzyjna ocena w tym zakresie jest praktycznie niemożliwa. Według badań Polskiego Związku Głuchych, zgodnych z badaniami ze spisów powszechnych, liczba osób z uszkodzonym słuchem w stopniu znacznymi głębokim, a więc głuchych i głuchoniemych, na rok 1999 w Polsce wahała się pomiędzy 45 a 50 tysięcy, a osób z uszkodzonym słuchem w stopniu umiarkowanym, czyli słabosłyszących, pomiędzy 800 a 900 tysięcy. Por. B. Szczepankowski, Niesłyszacy - głusi - gtuchoniemi, Warszawa 1999, s. 46; Polski Związek Głuchych w sprawozdaniu z działalności statutowej za 2012 rok wykazał rejestrację 18889 członków niesłyszących i słabosłyszących oraz 23710 niezrzeszonych osób niesłyszących i słabosłyszących. Ponadto 1793 osoby z otoczenia osób niesłyszących. Razem 44392 osoby. Por. A. Dębski, Gluchoniemi w Polsce, www.arturdebski.pl/wiadomosci/gluchoniemi-w-polsce (1.02.2014).

A. Brücnker, Słownik etymologiczny języka polskiego, Krakowska Spółka Wydawnicza, Kraków 1927, s. 145. 
ludzi słyszących przed nimi”’ Kościół katolicki umocniony słowami św.Jana: „w miłości nie ma lęku, lecz doskonała miłość usuwa lęk” (por. 1 J 4, 18) od szeregu lat wychodzi naprzeciw oczekiwaniom niesłyszących jako inicjator licznych dzieł edukacyjnych i ewangelizacyjnych na rzecz tego środowiska. Ze względu jednak na specyfikę funkcjonowania tych ludzi w świecie duszpasterze niesłyszących potrzebują stałego, pokornego podejścia i pogłębionego studium z surdopedagogiki, aby rzetelnie pomagać osobom niesłyszącym w przyjmowaniu zbawczego orędzia Chrystusa.

Zadaniem niniejszego artykułu będzie prezentacja działań duszpasterskich na rzecz środowiska osób niesłyszących z uwzględnieniem wkładu Soboru Watykańskiego II. Na wstępie zostaną sprecyzowanie i rozróżnione pojęcia duszpasterstwa specjalnego i specjalistycznego. Następnie przedstawiony zostanie zarys historii duszpasterstwa niesłyszących. Na jego kanwie przeprowadzona zostanie analiza troski i braku troski Kościoła wobec osób niesłyszących po Soborze Watykańskim II.

\section{Wyjaśnienie pojęć}

Zostaną w tym miejscu wyjaśnione i sprecyzowane pojęcia duszpasterstwa specjalnego i specjalistycznego. Mówiąc o duszpasterstwie specjalnym, poruszamy się na gruncie teologii pastoralnej, zwanej też teologią praktyczną. Czym zatem jest to duszpasterstwo i - jeśli mówimy o niesłyszących - czy jest to duszpasterstwo specjalistyczne, czy może raczej specjalne i dlaczego w tym przypadku nie wystarcza duszpasterstwo tradycyjne? Współczesny Leksykon teologii pastoralnej pod redakcją ks. Ryszarda Kamińskiego nie wprowadza podziału na duszpasterstwo specjalne i specjalistyczne, a duszpasterstwo niesłyszących włącza w zakres duszpasterstwa specjalistycznego i określa jako „formę duszpasterstwa specjalistycznego zaadresowaną do osób pozbawionych słuchu od urodzenia bądź wczesnego dzieciństwa, gdy jeszcze nie rozwinęła się u nich umiejętność mówienia"8. Podobnie

\footnotetext{
Por. K. Kirejczyk, Głusi, Warszawa 1957, s. 3.

K. Półtorak, Niesłyszacych duszpasterstwo, [w:] Leksykon teologiipastoralnej, red. R. Kamiński, W. Przygoda, M. Fijałkowski, Lublin 2006, s. 569.
} 
ks. Kazimierz Półtorak, podkreślając niewystarczające oddziaływanie duszpasterstwa tradycyjnego wobec niesłyszących, pisząc o niesłyszących, posługuje się terminem „duszpasterstwo specjalistyczne”: „Duszpasterstwo parafialne tylko w pewnym zakresie zaspokaja potrzeby religijne inwalidów słuchu i ich rodzin. Wszechstronne zaspokajanie tych potrzeb wymaga duszpasterstwa specjalistycznego"'.

Inne stanowisko prezentują: wieloletni wykładowca du s z p a st e r st wa s p e cjal n e go w Instytucie Teologicznym w Tarnowie ks. Adam Nowak, a także zasłużeni duszpasterze niesłyszących: wywodzący się ze środowiska krakowskiego ks. infułatJerzy Bryła czy pochodzący z Piekar Śląskich ks. Konrad Lubos (1923-1999), pierwszy kierownik i jednocześnie referent Ogólnopolskiego Duszpasterstwa Głuchoniemych. Opowiadają się oni za podziałem na duszpasterstwo specjalne i specjalistyczne. Duszpasterstwo specjalne rozumiejąjako kolejne ogniwo duszpasterstwa ogólnego i stanowego, które podejmuje się rehabilitacji osób defektywnych religijnie. Według ks. Adama Nowaka duszpasterstwo specjalne to „fachowa posługa w sprawach religijnych i moralnych w odniesieniu do osób defektywnych, pozbawionych jakiegoś zmysłu, sprawności psychicznej lub dotkniętych jakimś innym kalectwem"10. Duszpasterstwo specjalne nie jest wyizolowanym bytem. Jest połączone z różnymi dziedzinami wiedzy, z których często korzysta. Można tu zaliczyć chociażby surdopedagogikę, medycynę, szczególnie otolaryngologię, psychologię, pedagogikę, socjologię, nauki teologiczne. Duszpasterstwo specjalne, a w nim duszpasterstwo niesłyszących wchodzi w skład teologii pastoralnej i z niej czerpie zasady. Tak rozumiane duszpasterstwo specjalne przygotowuje i włącza do życia Kościoła te osoby, które z powodu niepełnosprawności nie mogłyby w pełni czerpać z nauczania i źródła sakramentalnego Kościoła. Do takich osób ks. Nowak zalicza: niesłyszących, niewidomych i oligofreników. Ponadto zauważa on, że w odróżnieniu od tego rodzaju duszpasterstwa duszpasterstwo specjalistyczne jako przedmiot swojego zaangażowania włącza wyselekcjonowane grupy wiernych, takie jak: ubodzy, chorzy i ministranci ${ }^{11}$. Być może

\footnotetext{
$9 \quad$ Por. K. Półtorak, Duszpasterstwo niesłyszacych, dz. cyt., s. 160.

10 Por. K. Lubos, Ks. Bp Herbert Bednorz - Protektor Duszpasterstwa Specjalnego, „Śląskie Studia Historyczno-Teologiczne" 22 (1989), s. 41.
}

11 A. Nowak, Duszpasterstwo głuchoniemych, Tarnów 1983, s. 6. 
nazwa „specjalne” ukształtowała się od powiedzenia „ludzie specjalnej troski”, bo przecież te osoby potrzebują szczególnego zainteresowania i wsparcia od tych, którzy - ewangelicznie rzecz ujmując - wi ęcej otr zy mali.

\section{Zarys historii zagadnienia}

Pierwsze formy działalności na rzecz osób niesłyszących w świecie związane były z Kościołem ${ }^{12}$, i to właśnie Kościół katolicki na przestrzeni wieków trwał przy głuchych, prowadząc ewangelizację z wykorzystaniem języka migowego ${ }^{13}$. Początki jego działalności sięgają ósmego wieku ${ }^{14}$. Z tego właśnie okresu pochodzi nota historyka Kościoła angielskiego, św. Bedy ${ }^{15}$, który opisał posługę świętego biskupa Hexham, a potem Yorku, Johna z Beverley (zm. 721), który ok. 683 roku uczył osobę głuchoniemą mówić. Pierwszym znanym nauczycielem niesłyszących był żyjący w XVI-wiecznej Hiszpanii Pedro Ponce de Leon (1508-1584), benedyktyn. W XVII wieku w historii duszpasterstwa niesłyszących zapisał się biskup Genewy, św. Franciszek Salezy (1567-1622) - uznano mu to, że przygotowywał głuchoniemego chłopca o imieniu Marci do przyjęcia sakramentów. Dzięki tej posłudze jest dziś uznawany za patrona niesłyszących. Jedną z pierwszych szkół dla niesłyszących założył w Paryżu ks. Charles-Michel de l’Épée. Kontynuatorem jego działań był ks. Roch-Ambroise Sicard. Pierwszą w Polsce instytucją kościelną, która zajęła się wyłącznie pomocą niesłyszącym, był Instytut Głuchoniemych w Warszawie. Założył go w 1817 roku zasłużony ${ }^{16}$ dla polskiej surdopeda-

12 A. Nowak, Opieka duszpasterska głuchych, „Ateneum Kapłańskie” 76 (1984) 452, s. 84-95; Z. Staszkiewicz, Głuchoniemych duszpasterstwo, [w:] Encyklopedia katolicka, t. 5, pod red. L. Bieńkowskiego, kol. 1151-1152.

13 Effatha! Język migowy, red. B. Szczepankowsk i in., Warszawa 2005, s. 44.

14 Por. B. Szczepankowski, Słownik liturgiczny, dz. cyt., s. 16.

15 Beda (Bede) Venerabilis (ok. 672-735), uczony i kronikarz anglosaski, benedyktyn, doktor Kościoła, święty (kanonizowany w 1899 roku), autor Historii Kościoła angielskiego (Historia ecclesiastica gentis Anglorum).

16 Por. B. Szczepankowski, Osoby duchowne zasłużone dla polskiej surdopedagogiki, [w:] Pedagogika chrześcijańska. Tradycja - nowoczesność - nowe wyzwania, red. J. Michalski, A. Zakrzewska, Toruń 2010, s. 143-159. 
gogiki ks. Jakub Falkowski (1775-1848) ${ }^{17}$. W 1879 roku dwóch księży - Józef Hollak i Teofil Jagodziński opracowało pierwszy słownik języka migowego w Polsce ${ }^{18}$. W początkach XX wieku kształcenie niesłyszących dzieci przejęli świeccy pedagodzy, natomiast duchowni skupili się głównie na katechezie i posłudze sakramentalnej. Rok 1905 stał się przełomowym dla zorganizowanej działalności na rzecz osób niesłyszących w Polsce. W Katowicach zostało utworzone jedno z pierwszych stowarzyszeń zrzeszających dorosłe osoby niesłyszące: Katolischer Taubstummen Verein St. Joseph (Katolickie Stowarzyszenie Głuchoniemych im. św. Józefa). W niedługim czasie po tym wydarzeniu w 1909 roku ks. Jan Wolarz wprowadził nabożeństwa tłumaczone na język migowy, skierowane do dorosłych niesłyszących ${ }^{19}$. Po nim te nabożeństwa kontynuował ks. Maksymilian Wojtas. Z czasem zaczęły powstawać inne stowarzyszenia niesłyszących ${ }^{20}$. W swych nazwach podkreślały chrześcijański charakter. W 1953 roku w Panewnikach koło Katowic zaczęto organizować cykliczne szkolenia dla duszpasterzy i katechetów osób niesłyszących. Szkolenia prowadzili ks. Konrad Lubos i ks. Jan Urbaczka. W lutym 1958 roku z inicjatywy prymasa kard. Stefana Wyszyńskiego powstał Ogólnopolski Sekretariat Duszpasterstwa Głuchoniemych z siedzibą w Kurii Diecezjalnej w Katowicach. Jego opiekunem z ramienia Episkopatu Polski został bp Herbert Bednarz. Tylko w latach 1958-1972 przeszkolono w Polsce 1136 duchownych w dziedzinie katechizacji i duszpasterstwa niesłyszących ${ }^{21}$. W 1980 roku Kościół nawiązał współpracę z Polskim Związkiem Głuchych, co ułatwiło szkolenie kandydatów na duszpasterzy niesłyszących. Od 2001 roku z inicjatywy ks. Grzegorza Sokalskiego, duszpasterza niesłyszących diecezji gliwickiej i wykładowcy języka migowego, nieprzerwanie od roku 2001 do 2013 organizowane były dwutygodniowe letnie kursy języka migowego dla duszpasterzy i katechetów. Dotychczas wzięło w nich udział 220 osób. W każdej diecezji są ustanowieni przez biskupa miejsca

17 J. Bryła, Głusi słyszą, Kraków 1998, s. 52.

18 B. Szczepankowski, Niesłyszacy - głusi-głuchoniemi, dz. cyt., s. 300.

19 Por. B. Szczepankowski, Stownik liturgiczny, dz. cyt., s. 17.

20 Stowarzyszenia takie powstały: w Poznaniu (1919), Warszawie (1919), Łodzi (1920), Grudziądzu (1920), Bydgoszczy (1929), Wilnie (1932), Wejherowie(1933). Por. J. Pałyga, Ludzie szczególnej troski, Warszawa 2003, s. 42.

${ }_{21}$ Por. B. Szczepankowski, Niesłyszący, dz., cyt., s. 302. 
diecezjalni referenci niesłyszących, z którymi współpracują duszpasterze, siostry zakonne i świeccy, często wywodzący się ze środowisk ludzi niesłyszących. W punktach dla niesłyszących przynajmniej raz w miesiącu sprawowana jest msza święta niedzielna w języku migowym oraz istnieje możliwość spowiedzi w tym języku. W ramach duszpasterstw diecezjalnych organizowane są pielgrzymki, rekolekcje adwentowe, wielkopostne i okazjonalne, dni skupienia, kursy przygotowujące niesłyszących do zawarcia sakramentu małżeństwa, a także peregrynacje relikwii ${ }^{22} \mathrm{w}$ ośrodkach szkolno-wychowawczych dla dzieci i młodzieży niesłyszącej prowadzona jest systematycznie nauka religii.

\section{Troska czy beztroska soboru}

w sprawie duszpasterstwa niesłyszących?

Przeglądając historię duszpasterstwa niesłyszących, nie znajdzie się w niej jakiegoś konkretnego przełomu związanego z pracami II Soboru Watykańskiego czy latami następującymi bezpośrednio po nim. Zatem należy zadać pytanie, czy za przyczyną dokumentów soborowych dokonał się jakiś rozwój w stosunku do lat wcześniejszych? Jeśli tak, to jaki i w jakiej dziedzinie duszpasterstwa niesłyszących? Zastanawia, a nawet niepokoi fakt, że w skorowidzu rzeczowym dokumentów soborowych nie występuje ani razu słowo „niesłyszący”, „głuchy”, „głuchoniemy” ani nawet „niepełnosprawny”. Może wynika to z faktu, że sobór nie potraktował niesłyszących jako niepełnosprawnych. Prof. Bogdan Szczepankowski zaznacza, że osoby niesłyszące kulturowo są niepełnosprawne tylko relatywnie, w otoczeniu ludzi słyszących. Profesor wnioskuje, że w równej mierze można potraktować jako niepełnosprawne te osoby słyszące, które nie znają języka migowego. Taka „niepełnosprawność słyszących” jest

22 Z inicjatywy ks. Grzegorza Sokalskiego, duszpasterza niesłyszących diecezji gliwickiej, w roku 2012 przeprowadzona została ogólnopolska peregrynacja relikwii patrona niesłyszących, świętego Filipa Smaldone, kanonizowanego 5 października 2006 przez Benedykta XVI. Relikwie zostały sprowadzone do Polski z Lecce we Włoszech, gdzie posługuje założone przez świętego Zgromadzenie Sióstr Salezjanek Najświętszych Serc, całkowicie poświęcone pracy na rzecz ludzi niesłyszących. 
doskonale widoczna, gdy osoba, która słyszy, ale nie zna języka migowego, znajdzie się sama w otoczeniu osób niesłyszących ${ }^{23}$. Czuje się ona wyobcowana i niedostosowana do życia w takiej grupie, można powiedzieć: niepełnosprawna.

Wydaje się, że niesłyszący, a także niewidzący czy oligofrenicy zostali w dokumentach soborowych potraktowani zbiorowo i zaliczeni do osób chorych czy ubogich, o których dokumenty wspominają w wielu miejscach. Zatem należy zadać pytania: co twórczego sobór wniósł do efektywniejszego działania duszpasterstw specjalnych? Do jakich inicjatyw poprowadził ich duszpasterzy?

Odpowiadając na te pytania, warto podkreślić, że sobór zwrócił szczególną uwagę na ewangelizację wszystkich ludzi. W jego dokumentach czytamy, że Kościół jako wspólnota wiary, nadziei i miłości wszystkich wierzących ${ }^{24}$ jest powołany do przekazywania zbawienia wszystkim swym członkom. W deklaracji o wychowaniu chrześcijańskim sobór naucza: „Wszyscy chrześcijanie jako dzieci Boże mają prawo do wychowania w duchu Ewangelii, a więc do pełnego uczestnictwa w życiu sakramentalnym"25. Podobnie czytamy w konstytucji dogmatycznej o Kościele, która obok uczestnictwa w życiu sakramentalnym wszystkich wiernych zauważa prawo każdego wiernego do korzystania z dóbr Kościoła zawartych w słowie Bożym: „każdy chrześcijanin ma prawo w obfitości otrzymywać duchowe dobra Kościoła, zwłaszcza pomoc słowa Bożego i sakramentów”26. Te stwierdzenia soborowe są zgodne z duchem Ewangelii, który bardzo dobrze wyraża się w słowach św. Pawła: „Bóg [...] pragnie, by wszyscy ludzie zostali zbawieni i doszli do poznania prawdy" (por. $1 \mathrm{Tm}$ 2, 4). Jeżeli stwierdza się „wszyscy”, to na pewno i osoby niesłyszące, które zostały przecież wezwane do szczególnego naśladowania Chrystusa w niesieniu Jego krzyża. Troskę ojców soborowych o osoby niesłyszące można wnioskować także z słów dekretu o pasterskich zadaniach biskupów w Kościele: „Specjalną troską należy otoczyć tych wiernych, którzy ze względu na warunki życia

\footnotetext{
B. Szczepankowski, Niesłyszący, dz. cyt. s. 14. Sobór Watykański II, konst. Lumen gentium, 8. Sobór Watykański II, dekl. Gravissimum educationis, 2.

Sobór Watykański II, konst. Lumen gentium, 37.
} 
nie mogą dostatecznie korzystać z ogólnej zwykłej opieki duszpasterskiej proboszczów lub całkowicie są jej pozbawieni”"27. Osoby głuchonieme czują się opuszczone przez duszpasterza, gdy ów przez brak znajomości języka migowego, a czasami i dobrej woli, pozostawia je samym sobie. Często znajdują się wówczas sekty, które po odpowiednich lektoratach języka migowego próbują „zaopiekować się” takimi osobami, wyprowadzając je z Kościoła. Czasem zastanawia i niepokoi brak zainteresowania i pomocy niesłyszącym ze strony duszpasterzy. Jeśli tak zróżnicowany pod względem etnicznym i klasowym Kościół w Ameryce ${ }^{28}$ zaopiekował się całą falą emigrantów, wychodząc naprzeciw ich potrzebom religijnym, to znaczy, że można i trzeba dziś zająć się mniejszościami społecznymi. Potrzeba jest nagląca, bo chodzi o wieczne zbawienie ludzi, którzy nie mogą korzystać z propozycji duszpasterstwa ogólnego.

Sobór przyczynił się niewątpliwie do działalności duszpasterzy Kościoła na rzecz osób z duszpasterstw specjalnych i wielu z nich twórczo służy. Przykładem jest św. Jan Paweł II, który w każdej ze swych licznych podróży znajdował czas, aby spotkać się z osobami niepełnosprawnymi czy upośledzonymi ${ }^{29}$. W wystąpieniach cytował dokumenty soborowe, odnoszące się do opieki nad osobami chorymi i ubogimi. Napominał pełnosprawnych zgodnie z myślą soborową: ,Jako członkowie tej samej wspólnoty osoby niepełnosprawne mają prawo oczekiwać niezbędnej pomocy ze strony swoich zdrowych braci" ${ }^{30}$.

Dziedziną życia Kościoła, w której ojcowie soborowi wywarli poważny wpływ również w zakresie duszpasterstwa niesłyszących, jest liturgia. Konstytucja o liturgii świętej zachęca do pełnego, czynnego i świadomego udziału w liturgii. W dokumencie tym czytamy: „Duszpasterze powinni czuwać, aby czynności liturgiczne odprawiano nie tylko ważnie i godziwie, lecz także by wierni uczestniczyli w nich świadomie, czynnie i owocnie"31.

27 Sobór Watykański II, dekret Christus Dominus, 18.

28 Por. H. Sławiński, Między ciagłością a zmiana, Kraków 2008, s. 167n.

29 W. Chudy, Powołanie osoby niepetnosprawnej w nauczaniu papieża Jana Pawła II, [w:] Osoba niepełnosprawna i jej miejsce w społeczeństwie, red. D. Kornas-Biela, Lublin 1988, s. 123.

30 Jan Paweł II, Przemówienie podczas spotkania z osobami starymi, chorymi i ułomnymi (Wiedeń 01.09.1983), „L'Osservatore Romano” 4 (1983) 9, s. 10.

31 Sobór Watykański II, konst. Sacrosanctum Concilium, 48. 
Należy zwrócić uwagę, jak wielki trud towarzyszy także duszpasterzom niesłyszących, aby postanowienia soboru odnoszące się do uczestnictwa świadomego, czynnego i owocnego w liturgii, zostały spełnione. Przydałoby się wsparcie soboru z zaleceniem przygotowania tekstów liturgicznych dostosowanych do percepcji osób niesłyszących. $O$ wiele ułatwiłoby to i poprawiło komunikację w czasie sprawowanych liturgii dla niesłyszących.

Przełomem w sprawowaniu liturgii dla niesłyszących stało się zezwolenie Stolicy Apostolskiej na użycie języka migowego podczas sprawowania liturgii z udziałem osób głuchoniemych. W 1966 roku Stolica Apostolska, zapytana o możliwość użycia w liturgii dla głuchych języka migowego, odpowiedziała twierdząco. W „Notitiae Celebrationes” możemy przeczytać: "Język migowy może być użyty we wszystkich częściach liturgii, w których używa się języka narodowego"32. Ponadto priorytetowym ułatwieniem dla duszpasterzy niesłyszących stała się decyzja soboru o odwróceniu ołtarza i kapłana w stronę ludu. Pozwoliło to osobom niesłyszącym na odczytywanie mowy z ust, pod warunkiem że celebrans mówi wyraźnie, znajduje się blisko uczestników liturgii, a jego twarz jest dobrze oświetlona. Liturgia posoborowa dopuściła też osobę komentatora w liturgii, co jest istotne, bo nie wszyscy duszpasterze niesłyszących znają język migowy i mogą korzystać z posługi tłumacza wyjaśniającego obrzędy i znaki ${ }^{33}$.

\section{Podsumowanie}

Analiza historii duszpasterstwa osób niesłyszących oraz nauczania soborowego pozwala na wyciągnięcie wniosku, że sobór zwrócił uwagę na osoby niesłyszące w zawężonym zakresie, tylko przy okazji duszpasterstwa chorych. Nie potraktował ich indywidualnie i profesjonalnie, jak na to zasługują. Działania na polu duszpasterstwa niesłyszących rodziły się oddolnie, z inicjatywy gorliwych duszpasterzy.

${ }^{32}$ Chociaż pozwolenie pochodziło z okresu przejściowego, gdy pozwolenie na języki narodowe dotyczyło tylko czytań i niektórych modlitw mszalnych, nigdy później nie zostało cofnięte. Zob. „Notitiae Celebrationes” 2 (1966) s. 30.

${ }_{33}$ Referat wygłoszony przez ks. Jana Szywalskiego podczas Ogólnopolskiego Spotkania Duszpasterstwa Niesłyszących, Porszewice 20.03.2014. 
To, co trzeba zaliczyć do zasług soboru, to uwrażliwienie na fakt, że każdy chrześcijanin ma prawo korzystać ze skarbca Kościoła. Sobór wprowadził także ułatwienia w sprawowaniu liturgii dla niesłyszących, o czym była mowa wcześniej. Choć trzeba zauważyć, że i na tym polu są braki. Niesłyszący w Polsce do dziś nie doczekali się lekcjonarza mszalnego i modlitwy eucharystycznej ${ }^{34}$, przygotowanych z uwzględnieniem gramatyki języka migowego i percepcji osób niesłyszących. Patrząc jednak na gorliwą pracę kapłanów, sióstr zakonnych oraz świeckich zaangażowanych w duszpasterstwo niesłyszących, można żywić nadzieję na dopełnienie i dokończenie dzieł inspirowanych przez sobór, szczególnie w dziedzinie liturgii. Można też liczyć na powstanie całkiem nowych inicjatyw na polu tego duszpasterstwa w Polsce. Przykładem tego rodzaju działań jest chociażby przetłumaczone na język migowy i wydane w postaci płyt dvd tłumaczenie Ewangelii ${ }^{35}$. Inna ważna dla duszpasterstwa specjalnego inicjatywa to tworzenie internetowych stron duszpasterskich i ewangelizacyjnych dla niesłyszących. Na tym polu gorliwością wykazuje się wielu duszpasterzy, wśród nich na szczególną uwagę zasługuje ks. Grzegorz Sokalski, kapłan diecezji gliwickiej, który przygotowuje w języku migowym i umieszcza na stronie internetowej filmy ze słowem Bożym na niedzielę i święta oraz w Telewizji Zabrze prowadzi programy ewangelizacyjne i społeczne dla niesłyszących ${ }^{36}$.

Wieloletni duszpasterz niesłyszących w Raciborzu ks. Jan Szywalski celnie zauważa, że „duszpasterze niesłyszących są jak misjonarze. Muszą się nauczyć nieznanego języka, poznać kulturę i mentalność tych ludzi, aby doprowadzić ich do otwarcia na Boże słowo. Sobór sprzyja temu zadaniu, bo wyzwala z ciasnych przepisów na rzecz miłości, aby zbawić

34 Konferencja Episkopatu Niemieci Konferencja Episkopatów języka niemieckiego w 1970 wydały Obrzędy Mszy świętej dostosowane dla głuchoniemych. Tekst został zatwierdzony przez Kongregację Kultu Bożego. Modlitwa eucharystyczna została oparta w swej strukturze i treści na bazie drugiej Anafory Mszału Rzymskiego z wprowadzeniem wielu zmian i uproszczeń. Zob. A. Lameri, La preghiera eucaristica della Chiesa tedesca per i non udenti, „Rivista Liturgica” 90 (2003), s. 135.

35 Płyty trafiły nieodpłatnie do zainteresowanych niesłyszących, dając im dogodniejszą sposobność dotarcia do prawdy ewangelicznego orędzia. Fundatorami tego przedsięwzięcia byli duszpasterze głuchoniemych z Polski.

${ }_{36}$ Zob. www.gliwice-effatha.pl. 


\section{ks. Artur Hałucha}

każdego człowieka" ${ }^{37}$. Uważam, że tak pojęta posoborowa rzeczywistość duszpasterska zadaje pytanie także biskupom diecezji, czy w celu bardziej skutecznego dotarcia z głoszeniem Ewangelii niesłyszącym nie należałoby, ustanawiając diecezjalnych duszpasterzy niesłyszących, wspomóc ich zaangażowanie poprzez odciążenie ich posługi na polu duszpasterstwa ogólnego, a także wsparcia tworzenia centrum duszpasterstwa niesłyszących z włączeniem odpowiednio przygotowanych merytorycznie osób świeckich.

37 Referat wygłoszony przez ks. Jana Szywalskiego podczas Ogólnopolskiego Spotkania Duszpasterstwa Niesłyszących, Porszewice 20.03.2014. 


\section{Summary}

\section{Special ministry for example deaf ministry, and the Second Vatican Council}

The article presents the situation of the specific pastoral service after the Second Vatican Council with focus on the pastoral deaf service. At the beginning, the differences between the specific vs specialist pastoral service are clarified, classifying the deaf persons as for the specific pastoral service. Subsequently, referring to the history of the pastoral deaf service, the influence of the Second Vatican Council on the pastoral deaf service formation is analysed, with a particular emphasis on the situation in Poland. The performed analysis of the Council documents concerning the pastoral deaf care has proven carelessness rather than care for this group of people, attending them only with the poor and the sick. The Council has not been also a breakthrough moment for the pastoral deaf service as well as the activities in this field have been a bottom-up process, initiated by dedicated priests and consecrated or secular persons.

Keywords: pastoral service, deaf person, pastoral care

Duszpasterstwo specjalne na przykładzie duszpasterstwa niesłyszących a II Sobór Watykański

W powyższym artykule została przedstawiona sytuacja duszpasterstwa specjalnego po Soborze Watykańskim II na przykładzie duszpasterstwa niesłyszących. Na wstępie wyjaśniono różnice pomiędzy duszpasterstwem specjalnym a specjalistycznym, kwalifikując osoby niesłyszące w zakres duszpasterstwa specjalnego. Następnie na kanwie zarysu historii duszpasterstwa niesłyszących przyjrzano się wpływowi Soboru Watykańskiego II na kształtowanie tegoż duszpasterstwa, ze szczególnym zaznaczeniem gruntu Kościoła w Polsce. Przeprowadzona analiza dokumentów soborowych pod kątem objęcia troską osób niesłyszących wykazała raczej brak troski niż troskę soboru wobec tych osób i zajęcie się nimi tylko przy okazji osób chorych i ubogich. Sobór nie okazał się też momentem przełomowym w dziedzinie duszpasterstwa niesłyszących, a działania na polu tego duszpasterstwa rodziły się oddolnie z inicjatywy gorliwych duszpasterzy, osób konsekrowanych i zaangażowanych świeckich.

Słowa kluczowe: duszpasterstwo, osoby niesłyszące, opieka duszpasterska

\section{Bibliografia}

Brückner A., Słownik etymologiczny języka polskiego, Kraków 1927.

Bryła J., Głusi słyszą, Kraków 1998. 
Chudy W., Powołanie osoby niepełnosprawnej w ramach nauczania papieża Jana Pawła II, [w:] Osoba niepetnosprawna i jej miejsce w społeczeństwie, red. D. Kornas-Biela, Lublin 1988, s. 123-149.

Dębski A., Głuchoniemi w Polsce, www.arturdebski.pl/wiadomosci/gluchoniemi-w-polsce (01.02.2014)

Dz.U. z 2011 nr 209 poz. 1243, www. isap.sejm.gov.pl (07.08.2014).

Effatha! Języ migowy, red. B. Szczepankowski i in., Warszawa 2005.

Encyklopedia katolicka, t. V, red. L. Bieńkowski i in., Lublin 1989.

Jan Paweł II, Przemówienie podczas spotkania z osobami starymi, chorymi i ułomnymi, Wiedeń 1983, „L’Osservatore Romano” 4 (1983) 9, s. 10.

Kamiński R., Drożdż B., Duszpasterstwo specjalne, Lublin 1998.

Kirejczyk K., Głusi, Warszawa 1957.

Lameri A., La preghiera eucaristica della Chiesa tedesca per i non udenti, „Rivista Liturgica” 90 (2003), s. 135.

Leksykon teologii pastoralnej, red. R. Kamiński i in., Lublin 2006.

Lubos K., Ks. Bp Herbert Bednorz - Protektor Duszpasterstwa Specjalnego, „Śląskie Studia Historyczno-Teologiczne" 22 (1989), s. 41-49.

Nowak A., Duszpasterstwo głuchoniemych, Tarnów 1983.

Nowak A., Duszpasterstwo głuchoniemych, „Ateneum Kapłańskie” 76 (1984) 452, s. 84-95.

Pałyga J., Ludzie szczególnej troski, Warszawa 2003.

Referat wygłoszony przez ks. Jana Szywalskiego podczas Ogólnopolskiego Spotkania Duszpasterstwa Niesłyszących, Porszewice 20.03.2014. (w posiadaniu autora artykułu)

Sławiński H., Między ciaggłością a zmiana, Kraków 2008.

Sobór Watykański II, Konstytucje, dekrety, deklaracje. Tekst łaciński i polski, Poznań 1967.

Szczepankowski B., Niesłyszacy - głusi-głuchoniemi. Wyrównywanie szans, Warszawa 1999.

Szczepankowski B., Osoby duchowne zasłużone dla polskiej pedagogiki, [w:] Pedagogika chrześcijańska. Tradycja, nowoczesność, nowe wyzwanie, red. J. Michalski i A. Zakrzewska, Toruń 2010, s. 143-159.

Szczepankowski B., Słownik liturgiczny języka migowego, Katowice 2000. 